\title{
From Christianising Africa to Africanising Christianity: Some hermeneutical principles
}

\author{
Van der Merwe, Dirk \\ University of South Africa \\ dirkvdm7@gmail.com
}

\begin{abstract}
During the early church's initial expansion phase where congregations were established in Syria, Asia Minor, Achaia, Italy and Africa there were strong leadership structures in Alexandria, Carthage, Hippo Regius and Ethiopia. Over a period of two millennia the Christian church with a westernised character has spread all over Africa. Today there is a strong African consciousness and critical approach to Africanise Christianity, to decolonise it and to de-Westernise it. This research endeavours to contribute to the dialectic and critical debate and reasoning surrounding the Africanising of Christianity. There is the attempt, from a holistic perspective, to set some hermeneutical principles in place within this approach. This article approaches this topic from three perspectives. Firstly, it gives a brief overview of the spread and growth of Christianity into Africa with reference to six epochs to contextualise the reasoning in the following sections. Secondly, it points out some difficulties that were experienced during the rapid growth of Christianity and changes in its theology. During the past few decades Africa has not only endeavoured to regain its political and cultural identity, but also to claim an own Christian identity by Africanising Christianity. Thirdly, the article discusses some proposed hermeneutical principles that should be considered during the formation of a new Christian identity.
\end{abstract}

Key words

Christianising Africa; Africanising Christianity; decolonise; de-Westernise; hermeneutical principles

\section{Introduction}

In a review of the book How Africa Shaped the Christian Mind (Oden 2007) in Christianity Today, David Neff (2008) stated: "Many of the shapers of Christian orthodoxy were African". He would have had in mind Augustine, 
Tertullian, Origen, Clement, Anthony and Pachomius who are well-known African church leaders. Neff continues in his review

The story of Christian theology has been told from a European perspective. Oden wants to tell that story differently: classical Christian theology was heavily shaped by Africans. The language we used to worship the trinity, the received definitions of the Christ's two natures, the early church's methods for restoring repentant sinners, the basic patterns of monastic life, our fundamental approach to biblical interpretation, the church's devotion to its martyrs - all of these things have their roots in African theological debate, African prayer, and African bible study. (Neff 2008:n.p.)

Over a period of nearly two millennia the church has spread all over Africa. Over the past three centuries colonization critically influenced the character of the church in Africa. Over the past few decades a strong African consciousness and critical approach to Africanise Christianity developed, to decolonise it and to de-Westernise it. ${ }^{1}$ This research endeavours to contribute to the dialectic and critical debate and reasoning surrounding the Africanising of Christianity. The main objective of this research is to connect, from a holistic perspective, some hermeneutical principles to Africanise Christianity to be employed interactively. These "principles" already received attention in the past, although in this research some will be approached from different perspectives to constitute a more holistic and coherent picture which relate to the latest comprehensive hermeneutical approach in biblical hermeneutics. ${ }^{2}$ The three constituents in dialogue

1 This article uses the terms "African" and "Western" with the following meanings: The term "African" is used in a homogenous sense to include people in Africa who share similar values, norms and cultural traditions. Africa is a large continent with diverse African cultures, but share a harmonious sense of communality. This is unique to Africa, for African world-views, though diverse, are based on communal values (Kasambala 2005:300). The term "Western" denotes more than a geographical location. In this research it refers to the peoples and territories of Europe and the Americas and antipodes (i.e., Australia and New Zealand) settled by Europeans. "Western" and "European" are virtually synonymous terms, although the West includes areas into which Europeans expanded. "By 1500, 'European civilization' was one of many models that could have been emulated" (https://faculty.unlv.edu/gbrown/westernciv/wc201/ wciv2c1/wciv2c1lsec2.html).

2 See my publications on the most recent development in biblical hermeneutics: Reading the Bible in the $21^{\text {st }}$ century: Some hermeneutical principles: Part 1 and Part 2, both published in Verbum et Ecclesia, 36(1). 
(speaker - message [text] - hearer) receive attention simultaneously to constitute a more comprehensive approach in biblical hermeneutics.

This article investigates African influence on Christianity in three sections, namely "Christianising Africa prior to 1960", "Africanising Christianity after 1960" and "Some hermeneutical principles". In the first section five epochs are investigated and discussed. In the second section some difficulties are pointed out that were experienced during the rapid growth of Christianity in Africa. In the last section, "Some hermeneutical principles", the focus is on the inculturation of the gospel. ${ }^{3}$

This research is not presented as complete; ${ }^{4}$ instead the intention is to participate in the critical thinking about the interplay between the gospel message and African cultures, theology and church.

\section{Christianising Africa prior to 1960}

This section briefly reflects on the expansion of Christianity into Africa. There are many excellent research publications that deal with this topic. ${ }^{5}$ This section serves only to create context for the other two sections.

3 This article does not focus on a specific region or ethnic group in Africa. This author is aware of the danger of generalization which is un-academic. The objective is to focus on specific principles that are generally applicable.

4 This article was presented as a paper at the Center for Studies on New Religions (CESNUR) International Society for the Study of New Religions (ISSNR), Estonian Institute of Humanities, Tallin University, held on 18-20 June 2015. The theme of the conference was "Religious innovation and religious change in the $21^{\text {st }}$ century".

5 Some of the scholars who have tried to cover the total picture of expansion of Christianity in Africa are: Schreiter (1985; 2009); Baur (1994); Isichei (1995), Bediako (1995); Walls (1996); Sundkler \& Steed (2000); Kalu (2005); and Oden (2007). Then there are scholars like De Gruchy (1997), who only focus on specific church expansions. The information given in this essay is so little in comparison with the whole picture. Kollman (2010:3, 4, 30) in his excellent article Classifying African Christianities: Past, Present, and Future: Part One, gives a detailed list of references of the most published sources on the histories of Christianity in Africa that appeared from 1994 to 2000 . He points out that "the earlier histories ... produced large and comprehensive volumes and were single-author efforts". During the first decade of the $21^{\text {st }}$ century "a number of multi-author collections of essays on African Christianity" appeared (Kollmann 2010:4). His assumption about this is "that Christianity in Africa is now too fastgrowing and varied for any synoptic account by a single hand" (Kollmann 2010:4). This is just for orientation. 


\section{Apostolic Fathers epoch: Alexandria ${ }^{6}$, Carthage, Hippo Regius and Ethiopia $^{7}$}

Christianity in Africa was certainly not founded with European involvement like organised missions to Africa or colonialism. The roots of the Christianising of Africa reach back to the missions of the Apostles (Baur 1994:17). ${ }^{8}$ The Christian Church blossomed in North Africa for six centuries before the arrival of Islam in this region. In those early centuries C.E., Athanasius, Clement of Alexandria, Anthony, Pachomius from North Africa, Origen, Tertullian, and Augustine were the pillars on which the universal Church were standing (cf. Baur 1994:17).

During the second and third centuries North Africa became the centre of Christian activities and produced leaders such as Augustine and Tertullian. The fourth and fifth centuries were difficult for the church in North Africa. Doctrinal issues and internal struggles divided the church (Onyinah 2007:305-6).

\section{Intermediate Islamic epoch: Nubia, Ethiopia and Congo}

In the seventh century the political scene changed dramatically with the arrival of Islam in Africa. This had serious implications for the spreading of Christianity. The zeal for spreading the gospel was replaced by a yearning for political gain and expansion. When the Arabs invaded and occupied North Africa, which started in 640 C.E., the expansion and growth of Christianity were terminated (Baur 1994:17).

Fortunately the Coptic Orthodox Christian Church tradition survived in the region (Onyinah 2007:305-6). During 697 C.E., when the Arabs conquered Carthage, the Nubian King Mercurios arose to establish a Christian kingdom stretching from Aswan to the Blue Nile. The yielding

6 In an excellent essay De Gruchy (1997:24-39) explains the significance of the Coptic Orthodox Church in African Christianity.

7 For the founding of Christianity in Africa, I am very much dependent on the magisterial work of Baur (1994) and also the work of Onyinah (2007).

8 The Coptic, Catholic, Protestant and Pentecostal churches in Africa agree that the apostle Mark was the first apostle to Africa. It is stated that he was born in Cyrene in Pentapolis, Libya, somewhere between 5 and 15 C.E. This gives African Christians a great sense of identity. Their view that Jesus had the last supper with his disciples and that the first Pentecost happened at the house of Mary, Mark's mother, is rooted African Christianity (Oden 2011:31). 
of this kingdom to Turkish-Islamic attacks during 1270 C.E. contributed to the rebirth of the Ethiopian Church. Christianity then prospered in the mountains of Ethiopia. In 1527 C.E. much of this church was destroyed by an Islamic jihad. ${ }^{9}$

While this was happening in Egypt, King Afonso of the Congo came to the fore. He became the first Christian ruler south of the Sahara. Owing to his Christian convictions he dedicated himself for two decades to the establishment of a Christian kingdom. In 1526 C.E. King Afonso, in collaboration with his son, Bishop Henrique, developed a programme for evangelization which was implemented in all the provinces of his kingdom. After his death his successors maintained links with Rome for three centuries (Baur 1994:17).

\section{Missionary epoch}

Islamic resistance in North Africa prevented the Christian voice from being heard in the rest of Africa. This only changed much later, when missionaries became active in Africa (Onyinah 2007:305-6). ${ }^{10}$

West Africa was only introduced to Christianity in the $15^{\text {th }}$ century when Portuguese seafarers travelled around the African continent (Baur 1994:42). Portuguese commercial voyages played an important role in the spreading of Christianity to West Africa - Roman Catholic priests accompanied the Portuguese expeditions and spread Christianity among the Africans they encountered during their voyages. These priests, however, had very little success and little was accomplished (Onyinah 2007:306).

Although this Christian faith never really became established in Africa in these early years, it definitely became a reality of life for many Africans from a number of generations. Christianity was practised in some places for two to three centuries, for example in the kingdoms of Congo, Angola, Zimbabwe and Warri (Baur 1994:42).

9 Defined in the Merriam-Webster dictionary online as: "1: a holy war waged on behalf of Islam as a religious duty; also: a personal struggle in devotion to Islam especially involving spiritual discipline; 2 : a crusade for a principle or belief".

10 Sub-Saharan Africa was bombarded with Western Christianity. Missionaries endeavoured to evangelize the continent, "seeing to it that syncretism did not take place" (Onyinah 2007:305-6). 
During the $18^{\text {th }}$ century, the United Brethren or Moravian Church of Denmark and the Society for the Propagation of the Gospel also made various attempts to spread the Christian faith, but with little success. However, Christianity steadily established some roots in the $19^{\text {th }}$ century through the inspired missionary activities of organizations such as the Basel Mission, the Bremen Mission, the Wesleyan Methodist Society and the various Catholic missions. The $19^{\text {th }}$-century missionary activity was the result of the Protestant Awakening, with all its zeal and commitment (Onyinah 2007:306). ${ }^{11}$

\section{Church foundation epoch}

African church leaders only took control of Christian churches in Africa during the latter half of the $20^{\text {th }}$ century ${ }^{12}$ (Onyinah 2007:306). Prior to this the following happened:

The Emergence of African initiated churches created a platform for resistance against missionary activities in Africa. This was initially prompted by a black nationalist group branded as "Ethiopians". They were mainly opposed to and protested against white dominance in their churches (Onyinah 2007:306). A few elite groups receded to form African churches that seemed similar to the mission churches. Another group of people, often referred to as prophets, challenged the authority of the missionaries. They arose from the lower classes of society and had minimal or even no formal education. Although these prophets were not commissioned to do

11 Let us also acknowledge that missionary Christianity contributed extensively to the improvement of the African society. The major inputs included "the establishment of schools, the introduction of Western medical systems, and social advancement of African society, such as the abolition of capital punishment and slavery. In addition, the missionaries were responsible for promoting translation, including the creation of vernacular alphabets and production of grammars and dictionaries" for African languages (Onyinah 2007:306). Draper (2002:40) points out that "the insistence on the primacy of the Bible ... carried with it the requirement of literacy and hence schooling. The convert must, by all means, be able to read the Word of God for herself".

According to Onyinah (2007:306) these missionary efforts failed "to provide for the holistic needs of the people". For Africans, the spirit-forces remained real and life threatening. It is against this backdrop that some Africans started their independent churches.

12 In this section I concentrate on the influence of Pentecostalism on African Christianity See also Kalu (2008:vii), who argues that Pentecostalism "must be woven into the broader tapestry of Christian presence and African responses." 
so, they helped to spread the Christian message in Africa and found new churches. Although these churches attracted many adherents, they had serious weaknesses. Their lack of a theological framework and leaders' lack of accountability paved the way that these Pentecostal churches became very popular (Onyinah 2007:307).

The emergence of classical Pentecostal churches was the result of the growth of Pentecostalism in Africa. These churches were established under the patronage of foreign Pentecostal missions. Some indigenous people who had interacted with gospel groups shared their Pentecostal experiences and practices. These indigenous Pentecostal Christians then approached foreign missionaries to come and take control of their groups (Onyinah 2007:307). Consequently, after a short time, some of these churches "emerged as independent, indigenous classical Pentecostal churches" (Onyinah 2007:307). The Pentecostal theology also enticed the African psyche. Before long Pentecostalism was widespread throughout the continent. Many converts were won and members of mainline churches deserted their churches to join the Pentecostals (Onyinah 2007:308).

Another movement that contributed to the spreading of the Pentecostal experience across the continent was an established network of Christian unions that connected students across borders. Through sharing their personal experiences, many people were converted to Christ. Many people who joined the student movements and Pentecostal business fellowships that had emerged, left the mainline churches to join the Pentecostal movements.

The emergence of Neo-Pentecostal charismatic movements. ${ }^{13}$ The first NeoPentecostal charismatic churches originated in the college and university student ministries in the 1970s (Danfulani 2012:4). The second level comprised those that originated overseas, especially in the United States. The Charismatic movement began within the mainline churches in America (Danfulani 2012:43). A third level constituted those that originated within

13 Danfulani (2012:42) points out that Neo-Pentecostal charismatic movements started in Nigeria on the campuses of tertiary institutions. Today there is hardly a Christian church movement in Nigeria that has not been influenced in one way or the other by the rise of Neo-Pentecostal charismatic Christianity. 
Nigeria and quickly spread to other countries in West Africa (Danfulani 2012:45).

In response to their loss of members who joined the Pentecostal and African Initiated Churches, the mainline churches established renewal groups. Very cleverly, these renewal groups followed practices similar to those of Pentecostal churches: "they offered a theological response that corresponded to the religious and spiritual needs of Africans" (Onyinah 2007:309). Informal and spontaneous Pentecostal ways of worship like singing, drumming, the clapping of hands and dancing were introduced. This style of worship developed increasingly to become characteristic of African Christianity. This phenomenon is later referred to as the Pentecostalisation of Christianity in Africa. It changed the theology and practice of Christianity in Africa radically (Onyinah 2007:309).

Onyinah (2007:310) states that the following internal affairs contributed to the multiplication of churches: (1) the freedom of worship within Pentecostalism, (2) the lack of formal theological training, (3) the springing up of renewal groups, and (4) the recognition of God's calling in the life of the believer or the receiving of a new vision that could be taken as an instruction to begin a new church. Old churches continued to split, which resulted in the establishment of new churches. Ogbu Kalu (2005) rightly states: "Leadership becomes dependent upon proved worth and charisma and not upon inherent right. As soon as some detect a fault, a weakening of charisma or autocratic exercise of power, a split occurs." Consequently, many churches were founded.

Onyinah (2007:311) links the external affairs that led to the multiplication of churches with the inspiration coming from Western Pentecostal preachers. He states that charismatic renewal in Africa was strengthened by the ministries of some Western Pentecostal television evangelists, especially Americans such as "Oral Roberts, Kenneth Hagin, Kenneth Copeland, Reinhard Bonke, and later on Benny Hinn” (Onyinah 2007:311). Many sermons by African pastors were derived from materials drawn from these ministers. ${ }^{14}$

14 Onyinah (2007:311) is more positive about the African transformation than many other African theologians. He asserts that although the contemporary practices of African 
However, the greatest foundation of African churches occur during the colonial period, from 1880 to 1960. During this era a significant part of the modern church infrastructure was established, which facilitated the evangelisation process. According to Baur (1994:18), two critical factors emerged more than a half century ago. Firstly, African Christians were competent enough to differentiate between the essence of Christianity and its European influence. In the end only a minority quitted Christianity by either embracing Islam or turning back to their ancestral religion. The missionaries were only expelled from a few countries and this was interpreted as a transient phenomenon. Baur (1994:18) states that Christianity statistically "became the majority religion in most countries south of the Sahara" by 1990 .

\section{Africanising Christianity epoch}

In the post-colonial period things have drastically changed. Africa seeks an own unique religious identity and attempts to become a full contributor to world Christianity (Oden 2007:93). Over the past few decades many publications have emphasized the necessity for change and proposed ways to change.

\section{Conclusion}

This first section was to give a very brief orientation about how the Gospel spread through Africa. It is evident that African Christianity has grown extensively to become the principal religion in most countries south of the Sahara. Pentecostalism dominated African Christianity and a need for an own African Christian theology (identity) started to emerged. This has implications for the Africanising of Christianity. When colonialism ended politically, a new epoch emerged, namely the epoch of de-Westernised African Christianity.

Christianity were greatly influenced by Westerners; Africans have contextualized all of this to suit their purposes in such a way that it is no longer foreign. 


\section{Africanising Christianity after 1960}

According to Strang (1991:432) "decolonisation was in full swing during the 1960s". After decolonisation ${ }^{15}$, the need for an African reformation grew even stronger. Many African publications mention decolonisation and the need for an African reformation. ${ }^{16}$

There is a belief that African Christian identity will be safeguarded only when the Christian faith is construed in terms of traditional cultural categories. Along the way antagonisms, mistakes and problems have emerged. This section will point out some of these antagonisms, mistakes and problems to endorse the hermeneutical principles discussed in the last section of this article.

\section{Antagonisms, mistakes and problems that emerged}

\section{Missed opportunities: recognition, isolation and separation}

Nearly two decades ago, Maluleke (1997:5) made a vital loaded statement: "[T]he major works on African theology during the 1990s have indicated that African Christian Theology...is a dynamic, growing, multifaceted and dialectic movement built diachronically and synchronically upon contextualization and constant introspection."

Immediately after this statement Maluleke (1997:5) laments the missed opportunities of the church. He writes that the tempo of change was influenced by the multiple future African theologies that were suggested

15 Today new voices have been raised about decolonizing; the decolonizing of Christianity, of institutions, etc. This then raises the question what the difference is between decolonizing and de-Westernizing. Is there a difference or is it just a matter of semantics?

16 To mention but a few: African Theology: An Introduction (Setiloane 1986); African Theology in its Social Context (Bujo 1992); Christ the African King: New Testament Christology, From Liberation to Reconstruction: African Christian Theology after the Cold War (Manus 1993); Christianity in Africa: The Renewal of a Non-Western Religion (Bediako 1995); African Inculturation Theology: Africanizing Christianity (Metuh 1996); The Church in Africa in the Twenty-First Century: Characteristics, Challenges and Opportunities (McCain 2000); African Reformation: African Initiated Christianity in the 20th Century (Anderson 2001); The Will to Arise: Theological and Political Themes in African Christianity and the Renewal of Faith and Identity (Oladipo 2006); Toward a theology of inculturation (Shorter 2006); Theology Brewed in an African Pot (Orobator 2008); How God Became African: African Spirituality and Western Secular Thought (Ter Haar 2009); and Inculturation and the Christian faith in Africa (Kanu 2012). 
while the ground already captured was neglected. ${ }^{17} \mathrm{~A}$ further problem was that African theologies were likely carried out in isolated camps and affected intra-continental dialogue. Maluleke (1997:5) also suggests that the "construction, innovation and contextualization" of an African theology were mainly in the hands of African theologians and were unconnected to previous theologies and the African Christian life.

\section{Popular, one-sided and restricted publications}

The need for a reformation ${ }^{18}$ of and interest in African Christianity became apparent in a vast number of publications since the 1960s. African theologians have endeavoured to show how the gospel resonates with the categories of the traditional African worldview. Numerous publications from all over the continent have sought to fulfil this task. Efforts at theological construction fail to consider and incorporate the popular level of living. The result is, according to Shorter (2015:n.p.), ${ }_{19}^{19}$ "a notional theology...not couched...in the grammar of real assent - the imaginative expression of popular faith". Charles Nyamiti (quoted by Ross 1997:96) agrees that "none of the existing African Christologies have had any appreciable influence in the life of the African churches". Unfortunately the attempts to indigenise theology eventually floated "free from real experience" (Ross 1997:97). ${ }^{20}$

\section{A distorted perception}

A third problem is what I call a "distorted perception". Notwithstanding the decline of Christianity in other continents, it remains a strong religion on the African continent. The church is rooted in the African society in various forms. Sundkler and Steed (2000:3) point out that two Nigerian scholars, J.F. Ade Ajayi and E.A. Ayandele, have made the important claim that a fundamental error normally made by church historians is that they write about the history of African Christianity "as if the Christian Church

17 For some African scholars the process of inculturation has not yet begun, for others it has already come fare. Maluleke (1997:5) assumes that for the encouragement for the growth of African theology and to effect signifiant paradigm changes, "the ground already captured" has to be acknowledged and documented.

18 This term includes in this article both references to inculturation and African Christian Theology.

19 http://www.afrikaworld.net/afrel/shorter.htm,

20 See also Parratt (1995:107) on African theology today. 
were in Africa, but not of Africa" (cf. Oladipo 2010:33). Sundkler and Steed (2000:3) try to correct this distorted perception by stating that "[ $t$ ] he Church is no longer in Africa, but is now of Africa". I regard this as another distorted perception. The Christian church is not "now" of Africa ${ }^{21}$ - but was founded in Africa nearly 2000 years ago (see my introduction). Christianity has therefore ceased to be regarded exclusively as a Western religion. Although the Western world (northern hemisphere) was saturated with Christianity for many centuries, the pendulum has swung back to the south (Oladipo 2010:33).

\section{Endorsed de-Westernisation of the Church in Africa}

Many African theologians are antagonistic towards the so-called "West", the Western Christian religion, Western missionaries and so on. ${ }^{22}$ In his article entitled Black and African Theologies in the New World Order: A Time to Drink from our Own Wells Maluleke (1996:8-9) is very critical and antagonistic towards "Western arrogance" (1996:8) and the "guilt-sticken Christian West". Oladipo (2010:35) states that "[t]he Christian faith has been 'de-Westernized"' in Africa. The following quotations from Maluleke (1997) underscore the above statements about antagonism towards liberal Western missionaries in discussing a publication of Bediako (1995) who asserts that "Christianity be viewed, not as a Western religion, but as a non-Western one". Maluleke (1997) strongly disagrees with him and writes: "Africans must first cease to experience Christianity as alienating and foreign before they can start discussing Christianity as non-foreign and non-Western." Maluleke (1997) complains that many African churches continue to be Western in polity, theology, doctrine and worship. This is a reality and "cannot be swept aside by mere enthusiasm for an African brand of Christianity" (Maluleke 1997:7).

21 While European missionaries introduced Christianity several centuries ago to subSaharan Africa, it was not "of" the continent, but was planted "on" it. However, a remarkable feature of the Christian resurgence on the continent is the way it has won the hearts and minds of a wide range of people (Oladipo 2010:33-5).

22 De-colonizing also became very acute today. Sometimes it seems as if it has been used as a synonym for "de-Westernizing". 
Later Maluleke (1997:15) writes: "African theologies cannot proceed as if the only real intellectual challenge to Christianity is Western rationalism, Western technocracy and post-modernity." On the same page Maluleke states that for those Africans who became Christian, Christianity provides a convincing framework for a full and complete life. Therefore Africans should not wait for everything in the African life to be fulfilled by Christianity. He accuses liberal Western missionaries of being guilty of such a view (Maluleke 1996:15).

\section{Dichotomous ways of living}

In his article entitled African spirituality that shapes the concept of Ubuntu, Masango (2006:33) refers to most Africans' dualistic way of living. On the one hand changes are made in society; "old concepts of Western ways of thinking" change "into new African ways of life". On the other hand African Christian believers are still wrestling with issues of change in the church. They find themselves strangled by dualism: they practise the African way of life while they simultaneously adhere to foreign and Western Christian principles (Masango 2006:933). ${ }^{23}$ In this process they fit old Western concepts into new African ways of life. The exertions will continue (Masango 2006:933) and debates will continue to make them aware of this dualism: there are Africans who live Western lives and there are Africans who adhere to the African way of life. African theologians criticise Colonialism to be the cause of this dualism.

\section{A matter of semantics and praxis}

The last complexity concerns a matter of semantics. African scholars use the same words with different connotations and it is sometimes not clear what they mean when they use a particular word. Therefore, it is necessary to define briefly within which semantic field a word is used. What is meant by "gospel", "Christianity", "African theology", "syncretism" and "inculturation"? Should we speak about de-colonisation or deWesternisation or both?

23 According to Masango (2006:934) those Africans who have accepted Christianity as a way of life abandon those "who practiced an African way of life". 


\section{Conclusion}

African scholars ${ }^{24}$ agree on the necessity for an own African Christian theology and inculturation. In this section I have pointed out only some complexities and concerns referred to and discussed by African scholars. The complexities relate either explicitly or implicitly to the inculturation of African Christian Theology. In the following section I intend to present a few hermeneutical principles for the Africanising of Christianity.

\section{Some hermeneutical principles}

According to Burridge (2007:353) "we all have our presuppositions and ideologies and theological assumptions. Hence the hermeneutical circle can become a vicious circle, as we read our own prior concerns, beliefs and ideas into and then out of text". In this last part of the article the focus is on some critical principles which should be borne in mind during the reading and analysis of texts to be adapted and adopted in new contexts. In this context "texts" refer not only to "oral" or "literary" texts, but also to life overall.

\section{The necessity for continuous change}

Everything in the world is fluid, including Africa. Even Christianity is not cast in iron and stone. Rather, Christianity is cast in new forms and new understandings ${ }^{25}$ (De Gruchy 1997:38). What is changeable in the message and mission of the church has probably been the most crucial issue since the foundation of Christianity. In fact, the greatest polemics in the church revolved around what may be changed or may not be changed.

De Gruchy (1997:38) correctly points out that successful indigenous incorporation of aspects of the African culture into Christianity will result in the invention of new constructs and new understandings of Christianity. Bosch (1991:358) makes the statement that "The Christian faith never exists except as "translated" into a culture." The Christianity of the West

24 To name a few: Mbiti (1995); Bediako (1995); Danfulani (2012); Ela (1986); Kalilombe (1994); Kanu (2012); Maluleke (1996, 1997); Masango (2006); Metuh (1996); Obijole (2012); Oladipo (2006); Orobator (2008); Pato (1997).

25 Different forms of Christianity (Protestants, Catholics, Orthodox, and Pentecostals). 
is certainly not a replica of the primitive church in the first-century Mediterranean world. Throughout the epochs of history the character of Christianity has changed, though not its identity. The identity is evident in the corporate allegiance of the gospel of Jesus Christ, despite the multiple variations of interpretation: Western, Eastern, African, Orthodox, Catholic, Protestant, and Pentecostal. Despite the differences and divisions an ecumenical church still exists due to the safeguard of the core teachings of the Bible (cf. De Gruchy 1997:38).

\section{The inculturation of Christianity: a continuing African discourse}

Culture is an indispensable part of being human. It denotes the various patterns of the thinking, acting and feelings of human beings. Shorter (2015:1) compares culture with a "prism through which people view the whole of their experience".

Inculturation presents and re-expresses the gospel in configurations and expressions proper to a particular culture. This course of action results in the reinterpretation of both the gospel and the culture by being faithful to both. Anything less "would be a syncretism and not a synthesis - the juxtaposition of non-communicating meanings" (Shorter 2015:1).

The Christian transformation of a particular culture takes that culture seriously. It does not overwhelm that culture, but rather reinterprets it. This process results in the enrichment of the bona fide meaning of that culture (Shorter 2015:3).

Important during such a transformation process is to remain faithful to both "the tradition concerning Jesus and to the authentic values of African Christianity and culture" (Shorter 2015:10). That fidelity can only be achieved if there is a deep understanding of both the Christian dogma and tradition of faith and the African cultures (Shorter 2015:10).

In the rest of the article I discuss some principles to be considered in the already existing process of Africanising Christianity. 


\section{The duality of change}

According to De Gruchy (1997:38) there are two inescapable effects attached to the attainment of inculturation. ${ }^{26}$ Firstly, inculturation "results in new forms and understandings of Christianity". The character but not the identity of Christianity changes. The character of Christianity in Europe is not equal to that of the early church in the first-century Mediterranean world. Not even the Christianity brought to South Africa by Europeans in 1652 or the early missionary activities during the $18^{\text {th }}$ and $19^{\text {th }}$ centuries are identical to our present-day Christianity. Continuities and resemblances of general characteristics occur. A common allegiance to the gospel and the tradition of Jesus Christ ensues, despite varying interpretations. The reality of an ecumenical church endures despite diversities and schisms. Change leads to the emergence of something new. This is evident in the Coptic Church, which grew to be a church with a distinct cultural and national identity. Nevertheless, it still strongly affirms its apostolic faith (De Gruchy (1997:38).

Then, secondly, those who take the gospel seriously and accept it, discover that the Christian faith changes the character of their culture. This implies that change is not like a one-way traffic, but like two-way traffic. They are then consistently surprised when they see and experience the new forms in which Christianity are cast. This can be verified by taking cognizance of how "Christianity changed Hellenism more than Hellenism changed Christianity" (De Gruchy 1997:38-9). Bosch (1991:265) resonates to this stating that "Inculturation suggests a double movement: there is at once inculturation of Christianity and Christianization of culture."

While Christianity has transformed the lives of Africans, the religion has also undergone significant changes because of how Africans have interpreted it through their own cultural lens (Oladipo 2010:68; Onyinah 2007:312). The question remains whether this form of Christianity will

26 For Kato (1974:3) the term "contextualization" expresses a deeper concept in theology than indigenization. The term implies, according to him, to make concepts or ideals relevant in a particular situation. Within a Christian context, it tries to express the never-changing Word of God in ever-changing modes to be relevant. Although the gospel message was inspired, the modes of its expression were not. Therefore the contextualization of the modes of expression became a necessity (also Danfulani 2012:50-1). 
over time continue to meet the needs of African people and how it will relate to other expressions of Christian faith. Only time will tell (Onyinah 2007:312). ${ }^{27}$

The gospel can only be truly relevant to the African situation if it has to do with culture, and culture has to do with the total life of the person. The gospel is bound to transform religious presuppositions and so on. It will change the ideas of the person, who will remain an African, but the thinking of this person will be conformed to the image of Christ.

\section{The nature of change: boundaries and freedom}

Owing to the necessity for change and therefore also for "an African Christian Theology", change boundaries should be formulated. Although changes in the character of Christianity are necessary, Scripture sets certain limits and boundaries; within these, change is allowed but also restricted.

Distinction has to be made between central and peripheral truths. In his article entitled "Reading Scripture as Lutherans in the post-modern era", Voelz (2000:312) makes two important statements about discourse. He writes that (1) all discourse is context-bound ${ }^{28}$ and (2) "[a]ll discourse is perspective and partial". This implies that discourse is subjective and "does not convey... an easy comprehensive picture of reality" (Voelz 2000:321). ${ }^{29}$

Heyns (1974:172) offers a possible solution to this issue. He is of the opinion that two kinds of truth exist in Scripture: central $^{30}$ truth and peripheral ${ }^{31}$

27 See Shorter (2015:1ff) on the Christian transformation of African culture.

28 Voelz (2000:312) writes: "Words are used with the meanings that are contextualised temporally (they are appropriate to their time), contextualised socially and culturally (they reflect the social/cultural setting of their users), and contextualised literarily (they are dependent on their literary co-text)."

29 See also Arles (2014:17) on the way forward in making a relevant theology.

30 Heyns (1974:170; see also Van der Merwe 2015c:176) explains "central" to be the centre where related and relevant things converge. It refers to a specific truth on which attention is focused, the key which unlocks every word, text or book in the Bible. Central truths cannot be transformed or amended.

31 For Heyns (1974:170; see also Van der Merwe 2015c:176) the truths in Scripture are unequally distanced from the centre. Peripheral truths are further distanced from the centre, but are still relevant. These truths were culturally influenced. They refer to environment of the ancient Mediterranean world. They should not be easily ignored. The principles embedded in these truths are still relevant and applicable for believers today. 
truth. ${ }^{32}$ The insight of the Bible writers was detached from today's systematic and ordered knowledge of cosmology, physics and technical science. They held a different world view. Reality was formulated by the Bible writers as they experienced it, in their idiom of transcendence versus immanence. This implies that God's revelation was not entirely and comprehensively revealed to humans in timeless or eternal truths (Heyns 1974:173). This points towards respect for and the maintaining of central truths, and the reconsideration and reinterpretation of peripheral truths. Culturally bound peripheral truths should be reinterpreted according to the principles embedded in these truths and how they relate to the culture involved.

\section{Opt for an African Christian theology}

The appeal of African scholars for the Africanisation of Christianity should revolve around two things: (1) an own African theology, which is embedded in and applied to the various African cultures; (2) a theology that also remained true to the essence of the Gospel message.

\section{Defining African theology}

The particular history of a church and the culture within which church finds herself are not the only vessels within which a feasible theology can be formed and formulated (Ross 1997:97). This work argues for an African Christian theology to be at the heart of African Christian churches. Such a theology should consist of a Christian doctrine from which faith principles and the conduct of the church emanate. ${ }^{33}$ This work opts for an African Christian theology (see Maluleke [1997:5, 8], who uses the same terminology) as it would also be the case for a Western Christian theology or an Orthodox Christian theology (Liberation Christian theology). ${ }^{34}$

32 The idea of "central" emanates from the organic character of Scripture. Therefore, everything in Scripture relates to the "central" truth, which constitutes everything in Scripture to have sense and meaning (cf. Heyns 1974:172; see also Van der Merwe 2015c:176).

33 See the publications of Goba (1979:5); Danfulani (2012:62); Orobator (2008) and Obijole $(2012: 110,114)$ who agree on this point.

34 Maluleke (1997:6) states: "I assume that the phenomena of African Christianity and African theology are so closely related that the two terms may be used interchangeably. African theologies exist because of African Christianities, and without African theologies we would not have any sustainable African Christianities. African 
"Christian" identifies the religion in which the core beliefs are embedded, and "African" (or Western, Orthodox or Liberation, etc.) identifies the perspective of formulation.

\section{The centripetal points of Christianity}

Three things that should be at the centre of characterizing this religion in South Africa as Christian are the three non-negotiable creeds, namely "The Kairos creed", "The Apostle's creed" and "The Nicene creed". These creeds formulate the essence and identity of the Christian faith.

Guroian (2006:340) states that "the Resurrection is the culmination of the Passion story, the completion of Christ's saving work on the Cross, theliving, beating heart of Christian faith and hope”. Goppelt (1982:II, 128) adds to this statement: "For Paul's trust in God encompasses 'faith in Christ'." $\mathrm{He}$ interprets the familiar formula, "faith in Jesus Christ", as a summary of the confessional formula in Romans 10:9: “... because, if you confess with your mouth that Jesus is Lord and believe in your heart that God raised him from the dead, you will be saved." This implies that the person who believes in Jesus Christ has accepted the dying and resurrection of Jesus "as God's revelation of salvation” (Goppelt 1982:II, 128). See also Goba (1979:5) ${ }^{35}$; Danfulani (2012:62); Orobator (2008) and Obijole (2012:110, 114).

\section{Resources for an African Christian theology}

Four levels of resources can be distinguished: history; academia; ordinary people; and the Spirit and the Bible.

Christianities are therefore expressions of African theology." This author can agree on this point only when theology is used in a Christian context, although this is a matter of semantics. There are also African theologies related to African traditional religions where Christ do not even feature. See Maluleke (1997:6-8) for a detailed discussion of his point of view.

35 "African Christian theology, while taking seriously the cultural religious milieu in which it occurs, is and should be grounded on that which concerns us ultimately: our faith in God fully revealed in Jesus Christ. Without these criteria there can be no theology." 


\section{Theology grounded in history}

What does "history" mean? Here history has manifold references. It refers to the socio-historical circumstances in which the bible books were written, the history of the "Early African church fathers" and the history of "Eastern and Western Christianity".

The early African church fathers. Serious attention should be paid to the contributions of the early African church fathers to the formulation of Christian doctrine. "Theological debates, African prayer, and African bible study" on African soil during the first centuries of the existence of the church contributed to " $[\mathrm{t}]$ he language we used to worship the trinity, the received definitions of Christ's two natures, the early church's methods for restoring repentant sinners, our fundamental approach to biblical interpretation, etc." (Neff 2008). May Africa remain loyal to the classical Christian theology of the early African church fathers.

Bediako (1995:xi) points out that any form of Scriptural orientation needs a valid historical dimension. Bosch (1991:467) express this fact so profoundly: "...all theologies, including those in the West, need one another, they influence, challenge, enrich and invigorate each other." For him "inculturation" must become "interculturation". This means we should take "serious account of the developments and responses of Christians of other periods in the Christian story". He refers to the weak assumptions that "historical tradition of the church has little value in interpreting the realities of the modern Christian existence" (1991:467).

Bediako sets an excellent example of how to go about constructing African theologies. In his book, Christianity in Africa: the renewal of a non western religion (1995), he tries to connect second-century thinkers with the modern African writers who look at parallels, analogues and comparisons between the two eras. He also seeks to situate $20^{\text {th }}$ century (when he wrote the book) African theology within the organic tradition of Christian theology as a whole (Bediako 1995:xii

Christians can never dissociate themselves from the history of Christianity, Western theology or even Orthodox theology. Western theology has made vast contributions to theological insights and Western theologians were serious in their efforts to understand Scripture. Along the way they also made mistakes, and we should learn from these mistakes and guard against 
repeating them. African theologians should take cognizance of publications from the West and archaeological excavations done by Westerners, because these could be stepping stones to further and alternative cultural directions.

According to Oladipo (2010:34) Christianity has ceased to be an exclusively Western religion in our generation. Scholars who have studied in the Western world but who practically belong to the Church in the Global South are writing many important books on Christianity today. They have received advanced theological education from institutions of higher learning in the West, but do not belong to the West, despite living there. Indeed, much of their work is a celebration of the triumph of the Church in the non-Western world. For example, in 1995 Kwame Bediako, the Ghanaian Presbyterian Church leader and scholar, wrote a book entitled Christianity in Africa, but the subtitle of the book was more indicative of what he wanted to convey: The renewal of a non-Western religion. ${ }^{36}$

\section{Academia}

Each generation should not try to reinvent the theological wheel. Every generation should acknowledge the contributions of previous ones and continue to contextualize these in a new way for the present era and situation.

In his provocative article "Half a century of African Christian Theologies", Maluleke (1997:23) writes: "The contours of the emerging face of twentyfirst century African theologies must be sought in a thorough grasp of the ground captured so far, plus a keen awareness of new and emerging currents." Maluleke (1997:23) also says the following:

What about previous theologies? Am I suggesting that their usefulness consist only in terms of "the ground that they have captured" so that they are of no direct relevance now? No. The issues that were being addressed by these theologies are far from finished. South African Black theology needs to continue its anti-racist critique of African Christianity. It must also develop its tremendous strides in Biblical hermeneutics further. Nor have issues of Africanisation, inculturation, and identity expired. African theology

36 See bibliography. 
needs to continue addressing these issues. What I am saying is that in addressing these established and still relevant agendas, Black and African theologies will need to do so in consultation with insights from such emerging theologies as I have sketched above.

Although Maluleke's (1997:23; cf. also Dickson 1984:8) statement refers to the past of African theology, the principle embedded in this statement is veracious. We can never just ignore the history of the church in total, whether we agree or disagree. Billions of dollars have been spent on centuries of research (and archaeological excavations) into first- and second-century Christian publications and to obtain a better understanding of the sociohistorical ${ }^{37}$ environment in which Christianity originated.

\section{The community}

West's (1997:105) incorporation of the community in dialogue aimed at formulating African Christian theologies is invaluable. Bosch (1991) already refers to it, six years earlier, as "contextualization." West first explains that ordinary African Christians constitute the main group of Bible readers on the African continent. This group should therefore participate in the dialogue for an African theology. Second he says that contemporary "trends in biblical scholarship" - such as post-secularism, reader-response criticism, and liberation hermeneutics - force theologians to acknowledge the ordinary reader. Third, the reading strategies of ordinary Bible readers should receive attention. Fourth, biblical studies have to be reconnected with several forms of contextual theology, including the theology of African women, Black theology and African theology. Consequently biblical scholars must recognise the foundational resources that ordinary Bible readers bring with them to this task (West 1997:105). ${ }^{38}$

37 This is a collective reference, referring to economics, culture, and religious, political and social aspects.

38 Ross (1997:97) agrees with West (1997) on this point. He states that theology is also constituted from the dialogue between the biblical text and the vernacular world in Africa. This constituted theology needs more exploitation in conjunction with the concrete historical circumstances of the believing community within which this dialogue occurs. On this point, this author is of opinion, can African Independent Churches make significant contributions. 


\section{The Holy Spirit and the Bible}

Of all that has been said and done the most important is the acknowledgement that the Holy Spirit is the interpreter of the Bible. The Spirit guides believers into truth (Jn 14:23; 16:1-3). According to 1 Corinthians 2:13, the Spirit illumines "the minds of spiritual people to the understanding of Scripture" (Thiessen 1983:256).

\section{Conclusion}

During the past few decades a shifting in agency has taken place. Where the gospel message used to be communicated by white Westerners to Africans, Africans themselves now communicate the gospel in Africa. Where the gospel message is communicated and accepted, lives change and consequently during different eras and in different places the game of the gospel also changes and continues to change.

The character of Christianity is due to change and adaptation although the change of its identity should be non-negotiable. This should be applicable and relevant to all cultures where the Christian religion has been accepted. Africans are in the practice to understand and worship the God who incarnated through Jesus Christ. The early African church fathers and later missionaries communicated the gospel message to Africans in terms of their own idioms and cultural expressions (as in other parts of the world). They view this Trinitarian God according to their own spiritual awareness and existential realities.

What has occurred over the past decades is a steady renewal of the church in the southern hemisphere (cf. Oladipo 2010:35). In this research of Africanising Christianity some familiar hermeneutical principles have been highlighted and discussed, some from different perspectives. The intention is certainly not to reinvent the wheel but to create a holistic and coherent picture of various hermeneutical principles to be coherently be considered always in the inculturation process of Africanising Christianity.

Over the past few decades a paradigm shift has taken place with regard to biblical hermeneutics - a movement from a particular methodology (such as the historical-critical or text immanent or reception theories) to a more comprehensive approach in hermeneutics (the incorporation 
of various methodologies simultaneously) to do more justice to the interpretation of the Bible text. ${ }^{39}$ This research opts for a similar approach for the hermeneutics of Africanising Christianity. A comprehensive hermeneutical approach should be followed. The duality of change (culture and character of Christianity), freedom within boundaries, the respect of church history and to opt for an African Christian theology in which the triune God rightly features is argued to be interactive. The main focus should be that God became visible in Africa through Christ and the Spirit in the different cultures of Africa. The main objective of all this should be the glorification of this God.

\section{Bibliography}

Adamo, DT 2011. Christianity and the African traditional religion(s): The postcolonial round of engagement. Verbum et Ecclesia, 32(1):1-10.

Anderson, A 2001. African reformation: African initiated Christianity in the 20th century. Trenton Africa: Word Press.

Basic concepts of Western Civilization, 2017. West. [Online]. Available from https://faculty.unlv.edu/gbrown/westernciv/wc201/wciv2c1/ wciv2c1lsec2.html. [Accessed 03/01/2017].

Baur, J 1994. 2000 years of Christianity in Africa. Nairobi: Pauline Publications Africa.

Bediako, K 1995. Christianity in Africa: the renewal of a non-Western religion. Maryknoll: Orbis Books.

Borg, MJ 1994. Meeting Jesus again for the first time: the historical Jesus \& the heart of contemporary faith. San Francisco: Harper San Francisco.

Bosch, DJ 1991. Transforming Mission. Paradigm shifts in theology and mission. Maryknoll: Orbis Books.

39 See my publications on hermeneutics: Reading the Bible in the $21^{\text {st }}$ century: Some hermeneutical principles: Part 1 and Part 2, both published in Verbum et Ecclesia, 36(1). Also Rethinking Biblical hermeneutics for mobilizing Christian believers to proclaim the Good News in a post-secular age, published in Missionalia, 43(2). 
Bujo, B 1992. African theology in its social context. Maryknoll: Orbis Books.

Burridge, RA 2007. Imitating Jesus. An inclusive approach to New Testament Ethics. Grand Rapids: Eerdmans.

Callagher, CH 1995. Fire from heaven: the rise of Pentecostal spirituality and the reshaping of religion in the twenty-first century. Massachusetts: Addison-Wesley Publications.

Cilliers, JH 2008. Formations and movements of Christian Spirituality in urban African contexts. Paper presented at the conference Interkulturelle Religionshermeneutik - Das Verstehen des Fremden, Religion und Politik in Afrika. Berlin: Humboldt University.

Cook, CCH (ed.) 2013. Spirituality theology and mental health: multidisciplinary perspectives. London: SCM Press.

Danfulani, UHD 2012. African culture, Christ and the academia: The need to Christianise the African cultural matrix. Ogbomoso Journal of Theology, 17(1):39-73.

De Gruchy, JW 1997. From Cairo to the Cape: The significance of Coptic Orthodoxy for African Christianity. Journal of Theology for Southern Africa, 99:24-39.

Dickson, KA 1984, Theology in Africa. Maryknoll: London Orbis Books.

Douglas, JD (ed.) 1975. Let the earth hear his voice: International congress on world evangelization, Lausanne, Switzerland: official reference volume, papers and responses, Minneapolis: World Wide Publications.

Ela, J-M 1986. African Cry. Maryknoll: Orbis Books.

Falola, T 2005. Christianity and social change in Africa: essays in honour of J.D.Y. Peel. Durham: Carolina Academic Press.

Gibellini, R 1994. Paths of African theology. Maryknoll: Orbis books.

Goppelt, L 1982. Theology of the New Testament (Vol 2). Göttingen: Vandenhoeck \& Ruprecht.

Guroian, V 2006. I confess because I know of the resurrection. St. Vladimir's Theological Quarterly, 50(4):339-55. 
Isichei, E 1995. A history of Christianity in Africa: from antiquity to the present. Grand Rapids: Eerdmans Publishing Company.

Kalilombe, P 1994. Spirituality in the African perspective in Paths in African Theology, edited by R. Gibellini,. Mary Knoll: Orbis books. 115-135.

Kalu, OU (ed.) 2005. African Christianity: an African story. Pretoria: University of Pretoria, Dept. Of Church History.

Kalu, OU 2008. African Pentecostalism: An Introduction. Oxford: Oxford University Press.

Kanu, IA 2012. Inculturation of African Traditional Religious Values in Christianity. International Journal of Humanities and Social Science, 2(17):236-244.

Kasambala, AE 2005. The impact of an African Spirituality and cosmology on God-images in Africa: A challenge to practical theology and pastoral ministry. International Journal of Practical Theology, 9(2):300-329.

Kollman, PV 2010. Classifying African Christianities: Past, present and future Part one. Journal of Religion in Africa, 40(1):3-32.

Kriel, A 1989. Roots of African Thought: Sources of Power - a Pilot Study. Pretoria: University of South Africa.

Maluleke, TS 1996. Black and African Theologies in the new world order: a time to drink from our own wells. Journal of Theology for Southern Africa, 96:3-19.

Maluleke, TS 1997. Half a century of African Christian Theologies. Journal of Theology for Southern Africa, 99:4-23.

Manus, UC 1993. Christ, the African King: New Testament Christology.

New York: Peter Lang.

Masango, MJS 2006. African spirituality that shapes the concept of Ubuntu. Verbum et Ecclesia, 27(3):930-43.

Mbiti, JS 1986. Bible and Theology in African Christianity. Nairobi: Oxford University Press. 
McCain, D 2000. The Church in Africa in the twenty-first century: characteristics, challenges and opportunities. Africa Journal of Evangelical Theology, 19(2):105-130.

Metuh, EI 1996. African inculturation theology: Africanizing Christianity. Onitsha: Imico Books.

Neff, D 2009. Out of Africa. Christianity Today (28 February). [Online]. Available from: http://www. christianitytoday.com/ct/2008/ februaryweb-only/109-52.0.html. [Accessed 11/05/2015].

Oden, T.C. 2007. How Africa shaped the Christian mind. Rediscovering the seedbed of Western Christianity, Inter-Varsity Press, Downers Grove. [Online]. Available from: https://books.google.co.za/ books?id=CVQ KfPQQNpoC\&printsec $=$ frontcover\&dq $=$ How + Africa + shaped + the $+\mathrm{C}$ hristian+mind,\&hl =en\&sa=X\&ei=K7lQVee9MumU7Qbkq4CoCw\& ved=0CCIQ6AEwAQ\#v=onepage $\& \mathrm{q}=$ How $\% 20 \mathrm{~A}$ frica\%20 shaped $\% 20$ the $\% 20$ Christian\%20mind\%2C\&f=false, [Accessed 12/05/2015].

Oden, TC 2011. The African memory of Mark: reassessing early church tradition. Downers Grove: IVP Academic.

Obijole, OO 2012. The church and the gospel message in the African cultural context. Ogbomoso Journal of Theology, 171I(1):99-116.

Oladipo, CO 2006. The Will to Arise: Theological and Political Themes in African Christianity and the Renewal of Faith and Identity. New York: P. Lang.

Oladipo, CO 2010. African Christendom in the Twenty First Century. Ogbomoso Journal of Theology, 15(2):33-71.

Oliver, WH 2014. The formation of Christian theology in Alexandria. Verbum et Ecclesia, 35(1):1-13.

Olupona, JK \& Sulayman, S 1993. Religious plurality in Africa: essays in honour of John Mbiti. New York: Mouton de Gruyter.

Olupona, JK (ed.) 2000. African spirituality: forms, meanings and expressions. New York: Crossroad.

Onyinah, O 2007. African Christianity in the twenty-first century. World \& World, 27(3):305-314. 
Orobator, AE 2008. Theology brewed in an African pot. New York: Orbis books.

Parratt, J 1995. Reinventing Christianity: African theology today. Grand Rapids: Eerdmans.

Pato, LL 1997. Indigenisation and liberation. A challenge to theology in the southern African context. Journal of theology of Southern Africa, 99:40-46.

Peterson, CA [n.d.]. Dangers and Opportunities in the Contextualization of the Gospel. [Online]. Available from: www.wlsessays.net/files/ PetersonDangers.rtf. [Accessed 12/05/2015].

Ross, KR 1997. Doing theology with a new historiography. Journal of theology for South Africa, 99:94-98.

Schaaf, Y 1994. On their way rejoicing. The history and role of the Bible in Africa. Nairobi: Paternoster Press.

Schaff, P 1885. Fathers of the Second Century: Hermas, Tatian, Athenagoras, Theophilus, and Clement of Alexandria (vol. 2, AnteNicene Fathers, Christian Classics). Grand Rapids: Ethereal Library.

Schreiter, RJ 1985. Constructing local theologies. Maryknoll: Orbis Books. Schreiter, RJ 2009. Traditionalists, Muslims, and Christians. Interreligious encounters and dialogue. Amherst: Cambria Press.

Setiloane, GM 1986. African Theology: An Introduction. Johannesburg: Skotaville Publishers.

Shorter, A 2006. Toward a theology of inculturation. Eugene: Wipf and Stock Publishers.

Shorter, A 2015. Inculturation of African Traditional Religious Values in Christianity: How Far? [Online]. Available from: http://www. afrikaworld.net/afrel/shorter. htm. [Accessed 29/04/2015].

Smith, EW 1966. African Ideas of God: A symposium. London: Edinburgh House Press.

Strang, D 1991. Global patterns of decolonization, 1500-1987. International Studies Quarterly, 35:429-454. 
Sundkler, B \& C Steed 2000. A History of the Church in Africa.

Cambridge: Cambridge University Press.

Ter Haar, G 2009. How God became African: African spirituality and

Western secular thought. Philadelphia: University of Pennsylvania Press.

Thiessen, HC 1983. Lectures in Systematic Theology. Grand Rapids: Eerdmans.

Van der Merwe, DG 2015. Reading the Bible in the $21^{\text {st }}$ century: Some hermeneutical principles: Part 1. Verbum et Ecclesia, 36(1):1-8.

Van der Merwe, DG 2015. Reading the Bible in the $21^{\text {st }}$ century: Some hermeneutical principles: Part 2. Verbum et Ecclesia, 36(1): 1-8.

Van der Merwe, DG 2015. Rethinking Biblical hermeneutics for mobilizing Christian believers to proclaim the Good News in a postsecular age. Missionalia, 43(2):166-185.

Voelz, JW 2000. Reading scripture as Lutherans in the post-modern era. Lutheran Quarterly, 14(3):309-334.

Vonck, PJ 1968. The Problems of African theology. AFER, 11 (1):73-8. 